\title{
SPOŁECZNE, DEMOGRAFICZNE, EKONOMICZNE I GEOGRAFICZNE UWARUNKOWANIA ZARZAZDZANIA BUDŻETEM DOMOWYM W POLSCE
}

\author{
Damian Abramczyk \\ Wydział Ekonomiczny \\ Uniwersytet Marii Curie-Skłodowskiej w Lublinie
}

\begin{abstract}
Streszczenie
Podstawowym zadaniem gospodarstw domowych jest wydatkowanie, a tym samym zaspokajanie potrzeb jego użytkowników. Każdy z nas, bez względu na wiek, płeć, sytuację osobistą czy zdrowotną tworzy gospodarstwa domowe, wydatkuje, generuje dochody do budżetu rodziny. $\mathrm{Na}$ przestrzeni lat proces zarządzania dochodami i wydatkami ewoluował. W dzisiejszych czasach, w dobie ogólnego dostępu do informacji zmiany te są bardzo istotne. Jednak czy jesteśmy świadomi zmian w strukturze gospodarowania budżetem domowym oraz jego wpływie na społeczeństwo? $\mathrm{W}$ poniższym artykule przedstawiona zostanie struktura zmian $\mathrm{w}$ zarządzaniu budżetem gospodarstw domowych $w$ ujęciu demograficznym, ekonomicznym oraz społecznym w oparciu o dane statystyczne, empiryczne oraz dostępną literaturę naukową. Przedstawione zostaną wyniki badań Fundacji Kronenberga przy banku Citi Handlowy, dotyczące koniunktury gospodarstw domowych oraz postaw Polaków wobec finansów. Zostanie wybrany również najkorzystniejszy wariant zarządzania budżetem domowym oraz zostaną przedstawione wskazówki mające na celu upowszechnienie oraz usprawnienie procesu gospodarowania budżetem domowym.
\end{abstract}

Słowa kluczowe: budżet, budżet domowy, gospodarka, zarządzanie, dochody, wydatki, demografia, struktura.

JEL Class: D14, H31. 


\section{WPROWADZENIE}

Celem każdego przedsiębiorstwa jest odniesienie zysku poprzez sprzedaż dóbr bądź usług następnym ogniwom łańcucha gospodarczego. W ujęciu ekonomicznym gospodarstwa domowe są jego ostatecznym, a zarazem największym konsumentem. Główny Urząd Statystyczny definiuje je jako ,zespół osób spokrewnionych lub niespokrewnionych, mieszkających razem i wspólnie utrzymujących się lub jako osoba utrzymująca się samodzielnie, bez względu na to, czy mieszka sama, czy też z innymi osobami. Członkowie rodziny mieszkający wspólnie, ale utrzymujący się oddzielnie, tworzą odrębne gospodarstwa domowe" [Łysoń i in. 2017: 39]. Właśnie te konsumując podnoszą swoje kwalifikacje, a tym samym wywierają pozytywny efekt na rozwój sytuacji finansowej producenta, dla którego pracują. Są one swoistym generatorem jednego z najważniejszych czynników ekonomicznych - pracy. Gospodarstwa konsumując są zmuszone do ponoszenia wydatków, co łączy się z ryzykiem nieefektywnego zarządzania budżetem jakim dysponują. Problemy te mogą mieć podłoże w wielu różnych dziedzinach, badanych przez środowiska naukowe, co skłania nas do głębszej analizy przyczyn oraz determinantów ich powstawania. Jednak, czy w dzisiejszych czasach Polacy nieumiejętnie dysponują budżetem, który posiadają? Celem niniejszego artykułu jest przedstawienie i analiza struktury zarządzania budżetem gospodarstw domowych w Polsce w ujęciu demograficznym, społecznym i ekonomicznym. Pozwoli to odpowiedzieć na wcześniej postawione pytanie, a także na poszerzenie informacji dotyczących zarządzania budżetami domowymi oraz ocenę i wybór najlepiej prosperujących kategorii, które najefektywniej gospodarują swoimi finansami.

\section{ZARZADZANIE BUDŻETEM DOMOWYM, DOCHODY I WYDATKI GOSPODARSTW DOMOWYCH W POLSCE}

Definicja zarządzania budżetem domowym jest określana jako ogół świadomych i dobrowolnie wykonanych czynności, które mają za zadanie koordynowanie wysiłków dla ich realizacji w ramach struktury organizacyjnej, w której funkcjonują jego członkowie [Świetlik 2011: 4], w oparciu o wcześniej określone cele. Te mogą być odmienne i dostosowane zarówno do potrzeb wspólnych jak i do potrzeb indywidualnych jednostki tworzącej gospodarstwo. Osoby tworzące są zależne finansowo, gdyż są także pracownikami oraz konsumentami. Gospodarstwo posiada więc dochody i wydatki związane z zaspokajaniem bieżących potrzeb. Dochód definiuje się jako sumę wszystkich wpływów pieniężnych bądź materialnych pomniejszoną o koszty uzyskania przychodu oraz odpowiednie opodatkowanie. Wydatki natomiast stanowią sumę wszystkich zobowiązań, 
które musi uwzględnić gospodarstwo domowe by zapewnić sobie minimum egzystencji przy uwzględnieniu kosztów narzuconych przez organy państwowe. Poziom przeciętnych dochodów i wydatków per capita w latach 2003-2016 przedstawia wykres 1 .

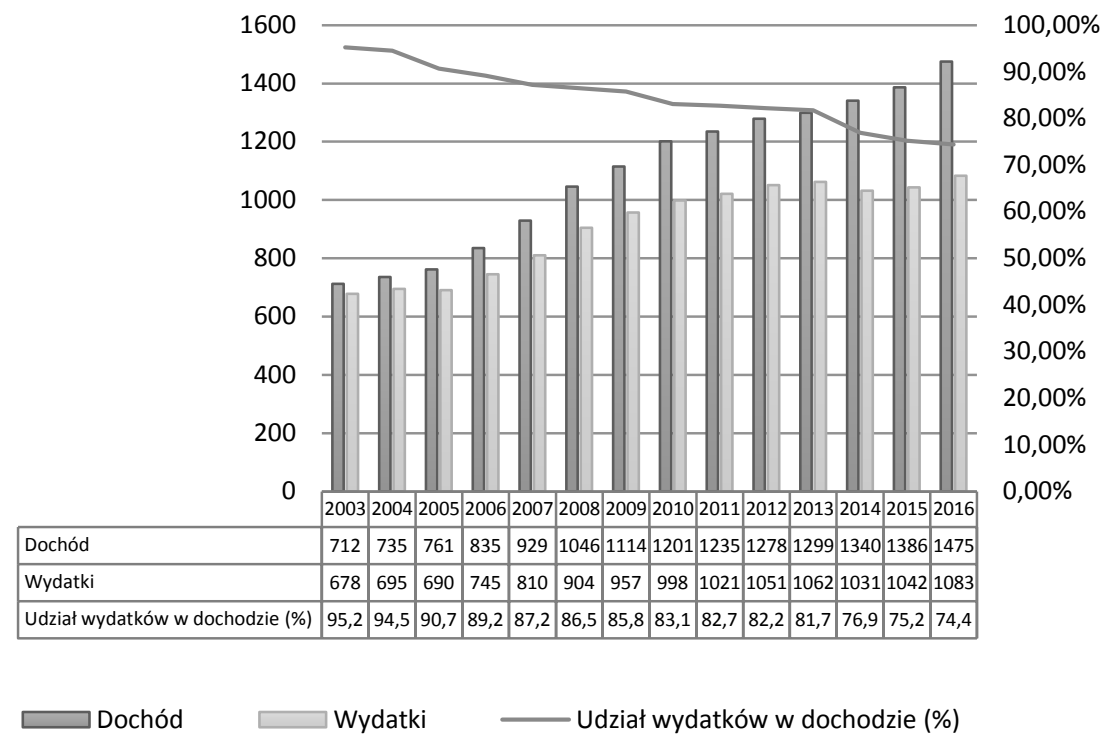

Wykres 1. Poziom przeciętnych dochodów i wydatków per capita w gospodarstwach domowych w latach 2003-2016

Źródło: opracowanie własne na podstawie Siwiak [(red.) 2014: 1]; Łysoń (red.) [2017: tab. 24; tab. 33]; Łysoń (red.) [2016: tab. 24; tab. 33]); Łysoń (red.) [2015: tab. 24; tab. 33].

Powyższe dane wskazują na nieustającą od kilkunastu lat tendencję wzrostową $w$ generowanym dochodzie. Oznacza to, że gospodarstwa domowe ciągle się bogacą. Wraz ze wzrostem dochodów gospodarstwa zgłaszają coraz większy popyt na dobra, a tym samym zwiększają swoje wydatki. Wzrost dochodu nie jest jednak wprost proporcjonalny do wzrostu wydatków. Obywatele są coraz bardziej przezorni. Do wybuchu wielkiego kryzysu w 2008 roku oszczędności, czyli nadwyżki dochodów nad wydatkami - były niewielkie. Później różnice te zaczęły być coraz bardziej widoczne, co świadczy o skłonności obywateli do oszczędzania pieniędzy na przyszłość.

Analizując szerzej strukturę dochodów i wydatków gospodarstw domowych nie można zapomnieć o strukturze każdego $\mathrm{z}$ badanych województw. Te różnią 
się od siebie specjalnościami, przez to także strukturą finansową gospodarstw. Bardzo istotny wpływ mają tu uwarunkowania historyczne, biologiczne oraz przyjęte wzorce konsumpcji. Warto uwzględnić, że Polska nie posiada wysokiego wskaźnika zróżnicowania terytorialnego względem norm Unii Europejskiej. Jednak w ostatnich latach zaobserwować można wzrost tychże wskaźników [Forlicz (red.) 2012: 202-203]. Najwyższy dochód na jednostkę w 2016 roku osiągnęli mieszkańcy województwa mazowieckiego - średnio 1 780,88 złotych przy wydatkach 1369,88 złotych. Niewątpliwie istotny wpływ na wynik tego badania ma obecność miasta stołecznego na terenie województwa, które daje wysokie możliwości rozwoju mieszkańcom zarówno miasta jak i całego Mazowsza. Województwo łódzkie uklasyfikowało się na 7. miejscu pod względem dochodu per capita osiągając średni wynik 1458,23 złotych przy wydatkach 1205,71 złotych. Natomiast województwo lubelskie zajmuje przedostatnią pozycję osiągając średni dochód 1 299,14 złotych per capita, przy wydatkach rzędu 1029,45 złotych. Na samym końcu rankingu znalazło się województwo podkarpackie, w którym na jednego mieszkańca przypada średnio 1 134,10 złotych przy wydatkach 902,18 złotych. Całkowite zestawienie średnich dochodów i wydatków województw w 2016 roku przestawia poniższy wykres.

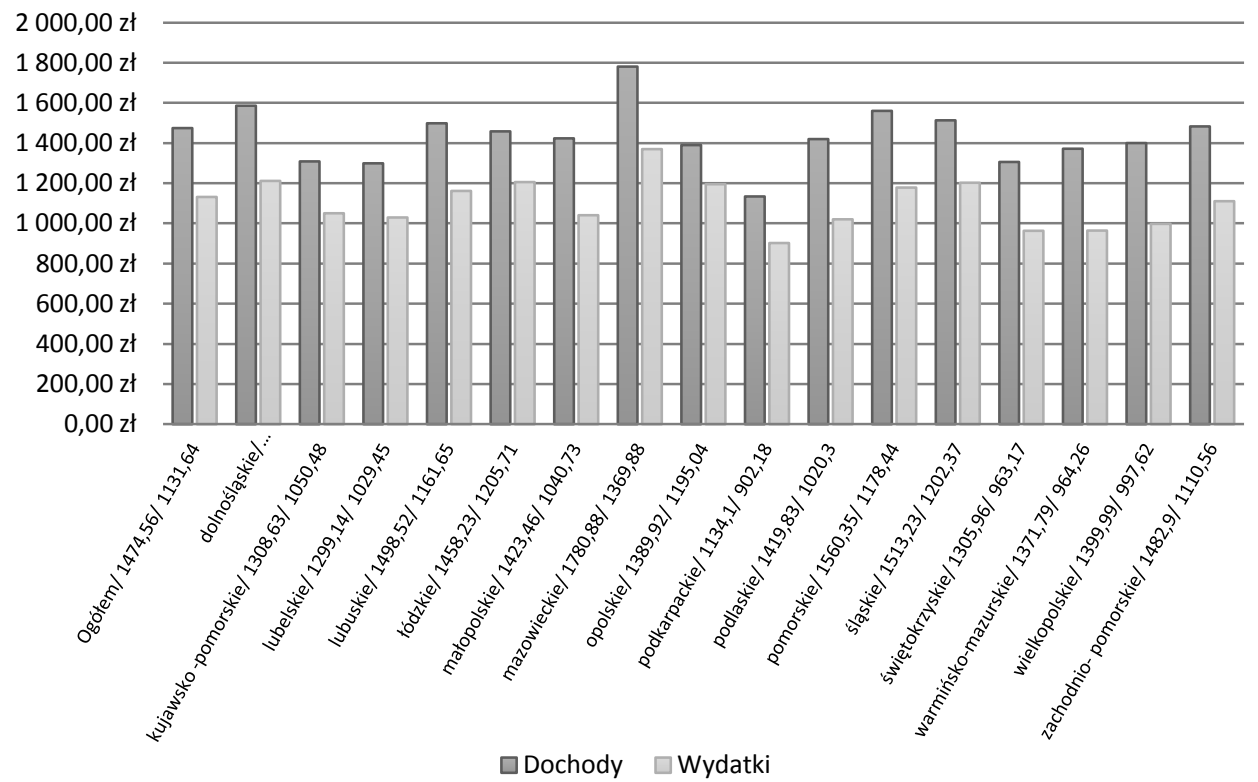

Wykres 2. Średnie dochody i wydatki gospodarstw domowych w przeliczeniu na 1 osobę wg województw w 2016 roku

Źródło: opracowanie własne na podstawie Łysoń (red.) [2017: tab. 25, tab. 36]. 


\section{CZYNNIKI MAJĄCE WPŁYW NA KSZTAŁTOWANIE SIĘ BUDŻETU ORAZ ZARZĄDZANIA GOSPODARSTWAMI DOMOWYMI}

Tworzenie budżetu domowego wiąże się bezpośrednio z generowaniem dochodu, za pomocą którego gospodarstwa są w stanie pokrywać swoje wydatki. Do jego pozyskiwania wykorzystuje się miejsca pracy, co jednocześnie stanowi bardzo istotną zmienną w kreowaniu struktury zarządzania gospodarstwami domowymi. Dane z 2017 roku pokazują zdecydowany wzrost zatrudnienia w wielu branżach:

- w branży przedsiębiorczej o $4,1 \%$,

- w przemyśle o 3,1\%,

- w handlu i naprawie maszyn samochodowych o 4,6\%,

- w branży hotelowej i gastronomii o 9,1\%,

- na rynku nieruchomości o 4,1\%,

- w dziedzinach naukowych, technicznych oraz profesjonalnej o 6,6\%,

- w administracji i działalności wspierającej o 9,4\%.

Jedyną branżą, która nie odnotowała wzrostu przeciętnego zatrudnienia jest branża budownicza, w której spadek, choć niewielki, wynosił w roku ubiegłym 0,3\%. Niewątpliwie ważnym czynnikiem determinującym wzrost gospodarczy jest stopa bezrobocia. W 2017 roku zarejestrowanych było 1 151,6 tys. osób poszukujących pracy [Poświata 2017: 24], co daje nam o 17,3\% mniej niż w czerwcu 2016 roku. Największy spadek bezrobocia miał miejsce w województwie pomorskim, natomiast najmniejszy w województwie kujawsko-pomorskim - odpowiednio o $22 \%$ i $13,3 \%$. W tym samym czasie stopa bezrobocia w Polsce wyniosła 7,1\%, co oznacza spadek o 1,6 p.p w stosunku do ubiegłego okresu sprawozdawczego. Jest to dobra wiadomość, zarówno dla producentów jak i konsumentów dóbr, gdyż wraz ze spadkiem bezrobocia zwiększają się możliwości konsumpcyjne i produkcyjne, co przekłada się na wyższe dochody. Przenosząc te wnioski w stosunku do gospodarstw domowych możemy stwierdzić źródła pochodzenia pieniędzy w gospodarstwach z osobą bezrobotną. Są to przede wszystkim zasiłki dla bezrobotnych, pomoc najbliższej rodziny, a także nowe świadczenia socjalne takie jak 500+ czy inne programy oferowane nam przez Rząd Rzeczpospolitej [Milic-Czerniak (red.) 1998: 81].

Aby dokonać porównania warunków wpływających na prowadzenie gospodarstwa domowego w poszczególnych województwach należy na początku zidentyfikować wskaźniki, które je determinują. W tym miejscu warto uwzględnić nie tylko stopę bezrobocia dla poszczególnych województw, ale także obciążenia związane $\mathrm{z}$ demografią panującą $\mathrm{w}$ danym regionie i wskaźniki zagrożenia ubóstwem. 


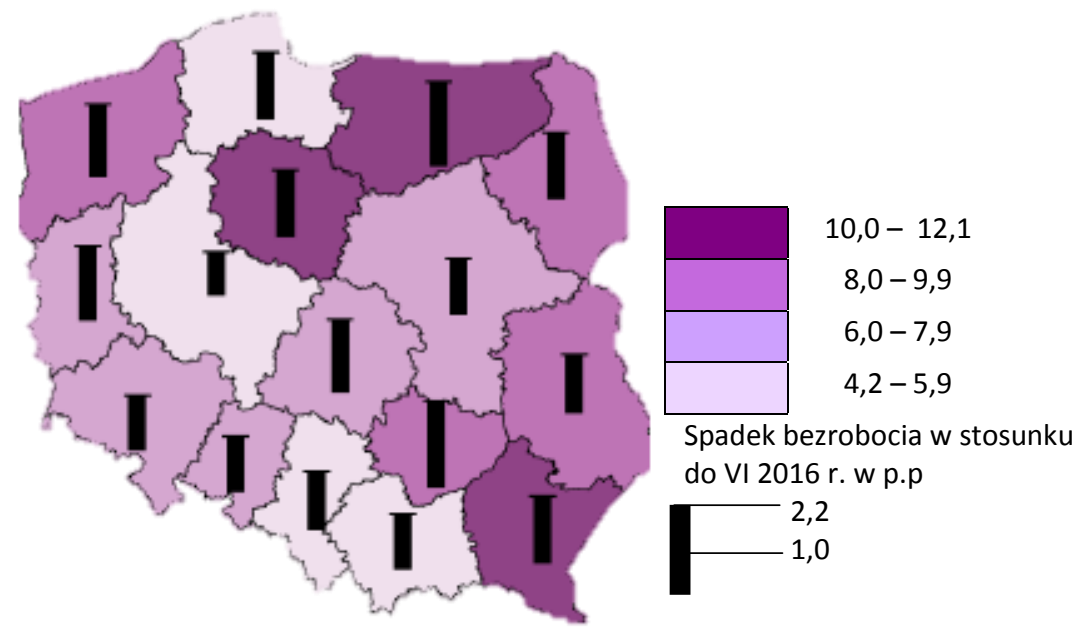

Rysunek 1. Stopa bezrobocia rejestrowanego w 2017 r.

Źródło: Poświata (red.) [2017: 24].

Wskaźniki demograficzne są dla każdego województwa bardzo zbliżone. Ilustrują nam struktury wieku, płci oraz zdolności produkcyjnych dla danego regionu. Inaczej jest w przypadku współczynników związanych z zagrożeniem ubóstwem, gdyż tych nie cechuje proporcjonalność wyników. Z tego względu, niektóre województwa odznaczają się wyższą skłonnością do ubóstwa. Są to województwa lubelskie, podkarpackie, świętokrzyskie, lubuskie. Natomiast najniższy wskaźnik zagrożenia ubóstwem posiada województwo śląskie - około trzykrotnie niższy od województwa lubelskiego.

Podstawowymi czynnikami demograficznymi, mającymi wpływ na zarządzanie budżetem domowym są niewątpliwie płeć i wiek jego zarządzających. Przeprowadzone badania wykazują, że prawie 6/10 kobiet planuje swoje wydatki za pomocą tradycyjnych metod, to jest kartki, długopisu i kalkulatora. Daje im to przewagę nad męską grupą badaną. Arkusz kalkulacyjny bądź inny program do kreowania budżetu domowego stosuje blisko 7/10 mężczyzn. Bardzo istotny jest także wiek respondentów. Okazuje się, że pomimo wieku nasza skłonność do tworzenia budżetu domowego jest stała i oscyluje wokół 60-63\%. Oznacza to, że prowadzenie budżetu domowego jest ważne zarówno dla ludzi młodych, jak i tych u schyłku swojego życia [Dryszel i in. 2012]. 


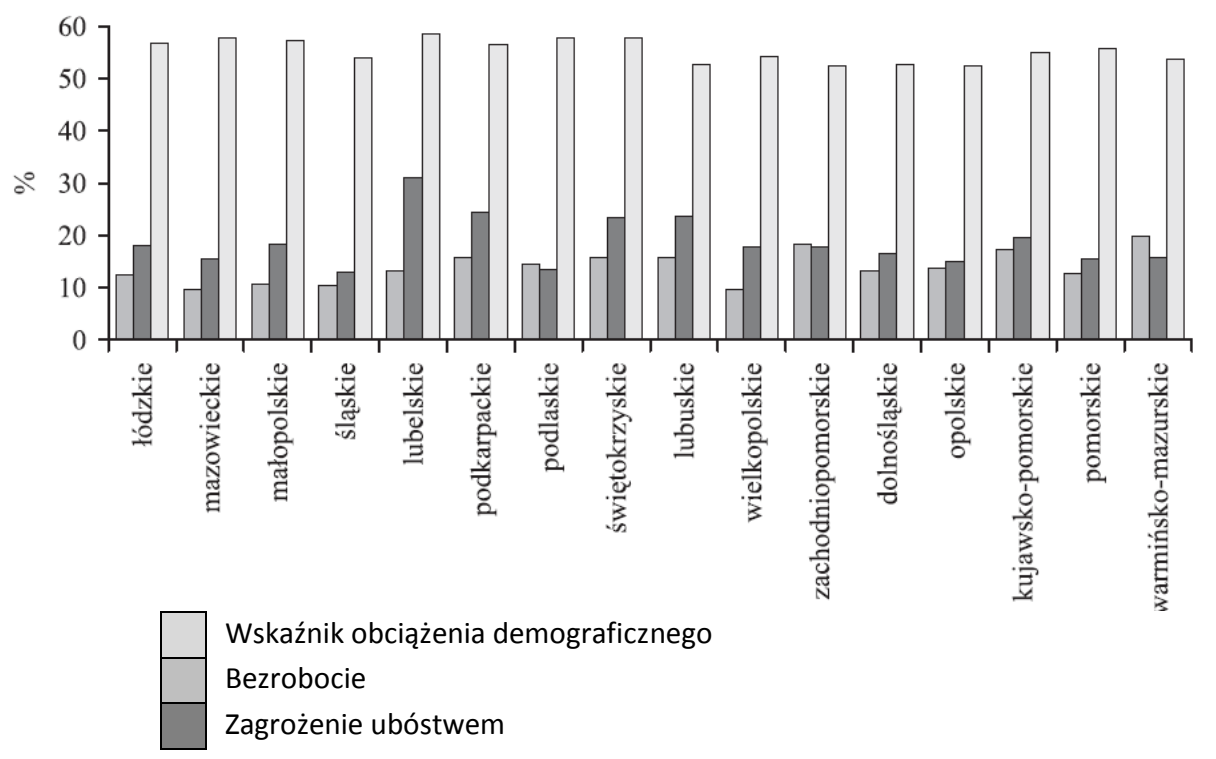

Wykres 3. Porównanie regionalnych wskaźników bezrobocia, zagrożenia ubóstwem i obciążenia demograficznego

Źródło: Forlicz (red.) [2012: 203].

Według statystyk Głównego Urzędu Statystycznego przeciętny emeryt wydawał około 1058 złotych na miesiąc, z czego 30\% zostało przeznaczone na żywność i napoje, $25 \%$ na koszty eksploatacyjne, $8 \%$ na ochronę zdrowia, a pozostałą część na środki transportu, kulturę, rozrywkę, łączność i napoje alkoholowe. Dane procentowe pokazują, że wraz z wiekiem zmieniają się także potrzeby konsumpcyjne konsumentów. Wyróżniono 7 faz rozwoju gospodarstwa domowego [Bywalec 2009: 117]:

- gospodarstwo samotnej młodej osoby,

- gospodarstwo młodego małżeństwa bez dziecka,

- gospodarstwo młodego małżeństwa z dzieckiem,

- gospodarstwo małżeństwa w wieku 30-45 lat z dziećmi w wieku szkolnym (7-19 lat),

- gospodarstwo małżeństwa w wieku średnim (46-60 lat) z dorastającymi i samodzielnymi dziećmi,

- gospodarstwo małżeństwa w starszym wieku po usamodzielnieniu się dzieci i opuszczeniu domu rodzinnego,

- gospodarstwo samotnej, starszej osoby, po śmierci współmałżonka.

Okazuje się, że bardzo istotny wpływ na sposoby zarządzania gospodarstwami domowymi w Polsce ma także stan cywilny osób badanych oraz umie- 
jętności racjonalnego dysponowania pieniędzmi. Ludzie pozostający w stałych związkach, którzy decydują się na wspólne zamieszkanie, na początku powinni odpowiedzieć sobie na pytania: jak danym budżetem zarządzać? Jak podzielić wspólne przychody i wydatki by te były jak najbardziej opłacalne? Naukowiec Jan Pahl pochodząca z Wielkiej Brytanii wyodrębniła 5 stylów w zarządzaniu budżetem gospodarstw domowych. Jak wspomniano wcześniej, czynniki wiekowe oraz płciowe stanowią fundamentalną podstawę $\mathrm{w}$ badaniu demografii naszego społeczeństwa. Nie inaczej okazało się w przypadku badań przeprowadzonych przez brytyjską naukowiec. Podzieliła ona style ze względu na osoby dominujące w zarządzaniu budżetem [Kopystyńska 2015: 6-7]:

1. Styl kobiecego zarządzania - polega na zarządzaniu finansami gospodarstw domowych przez kobiety oraz przekazywaniu przez mężczyznę całości jego wygenerowanych środków finansowych.

2. Styl męskiego zarządzania jest analogiczny do kobiecego spojrzenia na budżet, a więc to mężczyzna ma dominujący wpływ na sytuację finansową prowadzonego gospodarstwa.

3. Tworzenie nowego funduszu polega na rozdzieleniu wydatków na sfery odpowiedzialności. Oznacza to podział pieniędzy na wydatki wspólne oraz wydatki osobiste.

4. System wspólnej puli zakłada złączenie części bądź całości dochodów osób tworzących gospodarstwo domowe w jedną całość. W ten sposób tworzy się pula pieniężna, z której to uczestnicy opłacają swoje bądź wspólne wydatki

5. System niezależnego zarządzania finansami występuje, gdy każda osoba odpowiedzialna za tworzenie gospodarstwa posiada swoje środki oraz wydatki, które nie są zależne od innych uczestników budżetu domowego.

Warto wspomnieć, że pomimo prowadzenia różnych stylów gospodarowania budżetem domowym uczestnicy są świadomi swoim zarobków. Podstawową strukturą uczestników zarządzających budżetem jest związek małżeński dwojga ludzi, w którym rolę głównego żywiciela oraz funkcję kontroli przejmuje mężczyzna. Badania pokazują, że blisko 50\% ankietowanych deklaruje rozdzielność finansową, z czego największą popularnością cieszy się kobiecy sposób zarządzania finansami. Podkreśla to ich unikatowy i racjonalny sposób gospodarowania budżetem domowym.

W tym miejscu warto zaznaczyć także role tych osób, które mieszkają razem, lecz nie zawarły związku małżeńskiego. Okazuje się, że najczęściej wybieranym przez nich sposobem zarządzania budżetem jest system tworzenia częściowej puli na pokrycie wspólnych wydatków (zadeklarowane przez blisko $33 \%$ respondentów) oraz system niezależnego gospodarowania pieniędzmi $(29 \%$ badanych). 
Innym czynnikiem determinującym zarządzanie budżetem jest psychologiczne podejście do finansów. Z badań przeprowadzonych przez TNS OBOP [TNS OBOP 2006] wynika, że blisko 80\% gospodarstw domowych nie planuje swoich wydatków i nie przewiduje swojej sytuacji finansowej. Oznacza to zatrważająco niski poziom dyscypliny oraz kontroli wydatków. Czynnikiem mającym bezpośredni wpływ na taką sytuację jest zdecydowanie zbyt mała wiedza ekonomiczna i świadomość mieszkańców naszego kraju. Rezultatem tego są zwiększone kwoty utopionych wydatków, przeznaczonych na zaspokajanie bieżących potrzeb gospodarstwa. Jednak z biegiem czasu sytuacja ta poprawiła się, między innymi dzięki pojawieniu się specjalistycznych aplikacji komputerowych mających na celu usprawnienie procesu budżetowania w gospodarstwach domowych.

Z przeprowadzonych badań wynika, że zaledwie 30\% badanych osób tworzy rachunek przepływów pieniężnych swoich gospodarstw domowych, z kolei bilans budżetu domowego zaledwie $13 \%$, a $18 \%$ plan finansowy. Dane te wynikają z małej wiedzy ekonomicznej respondentów. 8/10 Polaków deklaruje, że tworzy budżet domowy w swoim gospodarstwie, z czego zaledwie $21 \%$ dokonuje tego raz w miesiącu. W prognozowaniu, planowaniu i uwzględnieniu dochodów i wydatków Polacy wykorzystują notatnik (23\% badanych), Program Microsoft Excel (9\% badanych), inny specjalistyczny program komputerowy (4\% respondentów) bądź bankowy (9\% ankietowanych), służący do zarządzania finansami gospodarstwa domowego [Musiał 2015: 238]. Około 36\% badanych stwierdza, że zakupy planuje $\mathrm{z}$ wyprzedzeniem poprzez listy zakupowe, natomiast około połowa ankietowanych stwierdza nieprzygotowane i nieprzemyślane zakupy.

Nowe technologie ułatwiają życie również w sferze finansów domowych. Wizja ciągłego zapisywania w zeszycie bądź komórkach Excela nie zachęca Polaków do prowadzenia ewidencji swoch gospodarstw domowych. Coraz większą popularność zdobywają aplikacje typu PFM (Personal Finance Management), które pozwalają na zebranie w jednym miejscu dochodów i wydatków, ustaleniu limitów czy zarządzanie posiadanymi funduszami [www1, dostęp: 7.06.2018]. Dodatkowo aplikacje te pozwalają na ocenę swoich wydatków z wydatkami średnimi o podobnym profilu zarobków czy miejsca zamieszkania. Aplikacje te to na przykład: Mit, Yoddle, Kontomierz czy programy łączące programy lojalnościowe sklepów takich jak Biedronka, Tesco czy wiele innych - aplikacja StoCard.

Bardzo istotny wpływ na sposoby i jakość zarzadzania budżetem domowym ma stan zdrowia jego użytkowników. Wraz ze wzrostem zachorowalności rośnie także skala wydatków związana z zakupem leków czy badań w celu jak najszybszego powrotu do pełnej sprawności. Według badań przeprowadzonych przez Główny Urząd Statystyczny 67,8\% [Ochrona zdrowia..., GUS 2011: 28] 
wszystkich gospodarstw domowych znajdowała się w miastach, a pozostała część na wsiach. U blisko połowy stwierdzono choroby przewlekle, w zależności od wieku pacjenta. To ważne informacje, gdyż wraz ze wzrostem odległości gospodarstwa domowego od placówki medycznej oraz powagi schorzenia, zmniejsza się również efektywność wyleczenia, a rosną koszty związane z zakupem leków oraz podróżą. Jak pokazują badania przeprowadzone w 2010 roku przez GUS, aż $97 \%$ ankietowanych stwierdziło wydatek związany z opieką zdrowotną, bądź zakupem leków. To potwierdza, że zdrowie jest ważnym czynnikiem determinującym życie obywateli. Co więcej, prawie połowa badanych $(48 \%)$ nie poniosła wydatków innych niż na leki. Wtedy to średni koszt pokrycia ochrony zdrowia na jedną osobę w ciągu roku wyniósł 52,50 złotych co stanowi wzrost o $28 \%$ w porównaniu do roku 2006. Struktura wydatków gospodarstw domowych przedstawia się następująco - zob. wykres 4 .

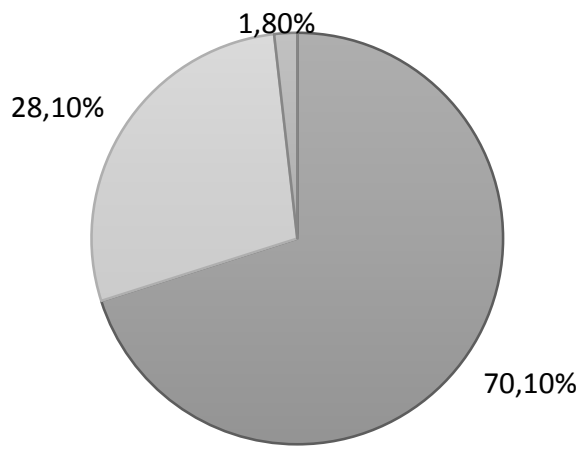

leki i artykuły medycze, medyczne dobra trwałego użytku

$\square$ ambulatoryjna opieka zdrowotna

$\square$ szpitale i inne zakłady

Wykres 4. Wydatki na opiekę zdrowotną w 2010 roku

Źródło: opracowanie własne na podstawie Łysoń [(red.), 2011: 57].

W 2010 roku wydatki na leki oraz artykuły medyczne wyniosły 64\%, co stanowi około 33,73 złotych na 1 osobę [Łysoń 2011: 57]. Wydatki te rosną także wraz z wiekiem ankietowanych osób. Dla porównania, w 2010 roku koszty związane z zakupem wyżej wspomnianych towarów przez emerytów wyniosły dwukrotność średniej na jednostkę. Co więcej, renciści na ten cel przeznaczali aż o 55\% więcej swoich funduszy. Oznacza to także istotność wieku na strukturę zarządzania wydatkami w budżecie domowym. Bardzo ważny wpływ miało także miejsce zamieszkania ankietowanych. Współczynnik zachorowalności jest 
znacząco wyższy w miastach niż na wsiach, co jest spowodowane między innymi trybem życia i środowiskiem jakie zamieszkują. Im większe miasto, tym większe wydatki ponoszą jego mieszkańcy, w związku z zapewnieniem sobie opieki zdrowotnej [Łysoń 2011: 57-58]. W 2010 roku gospodarstwa domowe o wyższych dochodach wydawały dwukrotnie więcej niż te, o budżecie najmniejszym.

W przypadku wydatków na ambulatoryjną opiekę zdrowotną aż 51,7\% zostało wydanych na rzecz opieki stomatologicznej, niewspieranej w ramach Narodowego Funduszu Zdrowia. Leczeniem specjalistycznym objęto 29,1\% wydatków na opiekę zdrowotną, a nieco ponad 19,1\% na pozostałe koszty związane z ambulatoryjną opieką zdrowotną.

W związku z tym na opiekę zdrowotną związaną z przebywaniem w szpitalach i innych zakładach opieki zdrowotnej gospodarstwa domowe wydały blisko 1 złoty na osobę w skali miesięcznej. Jest to kwota relatywnie niska, ponieważ stanowi ona uśrednioną wartość wszystkich osób tworzących gospodarstwo domowe. Warto zaznaczyć, że w Polsce opieka zdrowotna jest finansowana z Narodowego Funduszu Zdrowia, a badane gospodarstwa w 79\% nie stwierdziły obecności w szpitalu swojej bądź bliskiej osoby.

Warto pochylić się także nad problemem niepełnosprawności w środowisku gospodarstw domowych, co łączy się bezpośrednio z generowaniem dodatkowych kosztów na opiekę zdrowotną. Bardzo często osoby niepełnosprawne są niezdolne do wykonywania zawodu, przez co generują dodatkowe koszty nie wnosząc środków finansowych. To powoduje spadek średniego dochodu na jednostkę w gospodarstwie domowym. Badania wskazują na bardzo niski poziom funduszy, które mogłyby zostać przekazane na zakup leków. Prawie co czwarty rencista i osoba niepełnosprawna nie była w stanie zakupić leków, które zostały im przypisane przez lekarza [Łysoń 2011: 58]. Narodowy Fundusz Zdrowia wychodzi takim sytuacjom naprzeciw i zapewnia częściową bądź całkowitą refundację leków dla osób niepełnosprawnych. W 2010 roku z takiej propozycji skorzystał co dziesiąty obywatel z orzeczeniem o niepełnosprawności.

Biorąc pod uwagę stan cywilny oraz sytuację zdrowotną w gospodarstwach domowych powinno uwzględnić się również sytuację demograficzną rodzin, które gospodarują swoim budżetem. Statystycznie na jedną polską rodzinę przypada 1 dziecko, o czym świadczy współczynnik dzietności na poziomie 1,3 (dane z 2013 r.) [www3, dostęp: 27.02.2018]. Coraz powszechniej można zaobserwować zjawisko „dzieciocentryzmu” [Milic-Czerniak (red.) 1998: 132], polegające na nadmiernej koncentracji rodziców na swoich pociechach. Skupienie uwagi prowadzi do zwiększonych wydatków w tej sferze życia, szczególnie młodych rodziców, którzy dopiero zaczynają tworzyć pełnoprawne gospodarstwa domowe. Liczba dzieci jest niejako zdeterminowana przez region, z którego pochodzi grupa badawcza. W zachodniej części kraju dominuje model rodzi- 
ny jednodzietnej (dolnośląskie 58,5\%; zachodniopomorskie 57,5\%; lubuskie 55,5\% [www3, dostęp: 27.02.2018], natomiast na wschodzie możemy zauważyć tendencję do posiadania większego potomstwa (Podkarpackie 16,3\%, Podlasie 14,4\% i Lubelszczyzna 14,3\%). Warto zauważyć, że liczba posiadanych dzieci zmniejsza dochód per capita w gospodarstwie domowym.

\section{BADANIE POSTAW WOBEC GOSPODARSTW DOMOWYCH}

Zarządzanie budżetem gospodarstw domowych to proces nieustannie zmieniający się w czasie.

Wszystkie podmioty gospodarcze, w tym także opisywane w tym artykule gospodarstwa domowe, są istotnie podatne na zmiany w cyklu koniunkturalnym, a także na zmiany cen rynkowych czy innych kategorii ekonomicznych. Z tego względu, niezbędnym stało się przeprowadzanie cyklicznych badań koniunktury gospodarstw domowych oraz postaw mieszkańców wobec finansów.

Badania te, po raz pierwszy miały miejsce w Stanach Zjednoczonych Ameryki. Zostały one przeprowadzone przez Instytut Badań Ekonomicznych Uniwersytetu Michigan, już na początku lat 40. XX wieku. Analiza wyników dała podstawę do regularnego badania zachowań gospodarstw domowych w zależności od sytuacji i otoczenia rynkowego gospodarstw domowych [Bywalec 2009: 81-82].

Za pierwsze polskie badania koniunktury, realizowane systematycznie od 1990 roku uważane są badania Instytutu Gospodarczego Szkoły Głównej Handlowej [Bywalec 2009: 83]. Opierają się one na tak zwanym teście koniunktury i dotyczą ogólnej sytuacji ekonomicznej Polski oraz gospodarstw domowych - stanu bezrobocia, panującej inflacji, a także poziomie konsumpcji czy skłonności do oszczędzania pieniędzy. Wynikiem tych badań jest opracowany na ich podstawie wskaźnik kondycji gospodarstw domowych, którego wyniki na przestrzeni lat zostały przedstawione na wykresie 5. Wskaźniki pokazują nam tendencję wzrostową, co oznacza że kondycja polskich gospodarstw domowych nieustannie się poprawia. Ma na to wpływ wiele czynników, takich jak wcześniej wspomniany dochód czy determinanty opisane w poprzednich częściach artykułu.

Badania przeprowadzone przez Szkołę Główną Handlową nie były jednak jedynymi polskimi badaniami zwyczajów finansowych Polaków. Rokrocznie, od 2008 roku, Fundacja Kronenberga, działająca przy Banku Citi Handlowy dokonuje pomiaru wielu wskaźników dotyczących gospodarowania finansami domowymi. Głównym jego celem jest poznanie postaw Polaków wobec finansów [Postawy Polaków wobec finansów, 2015: 5]. Do jego realizacji, każdego roku, wykorzystano odpowiedzi średnio 1000 osób powyżej 15 roku życia. Jego wyniki są zaskakujące. 

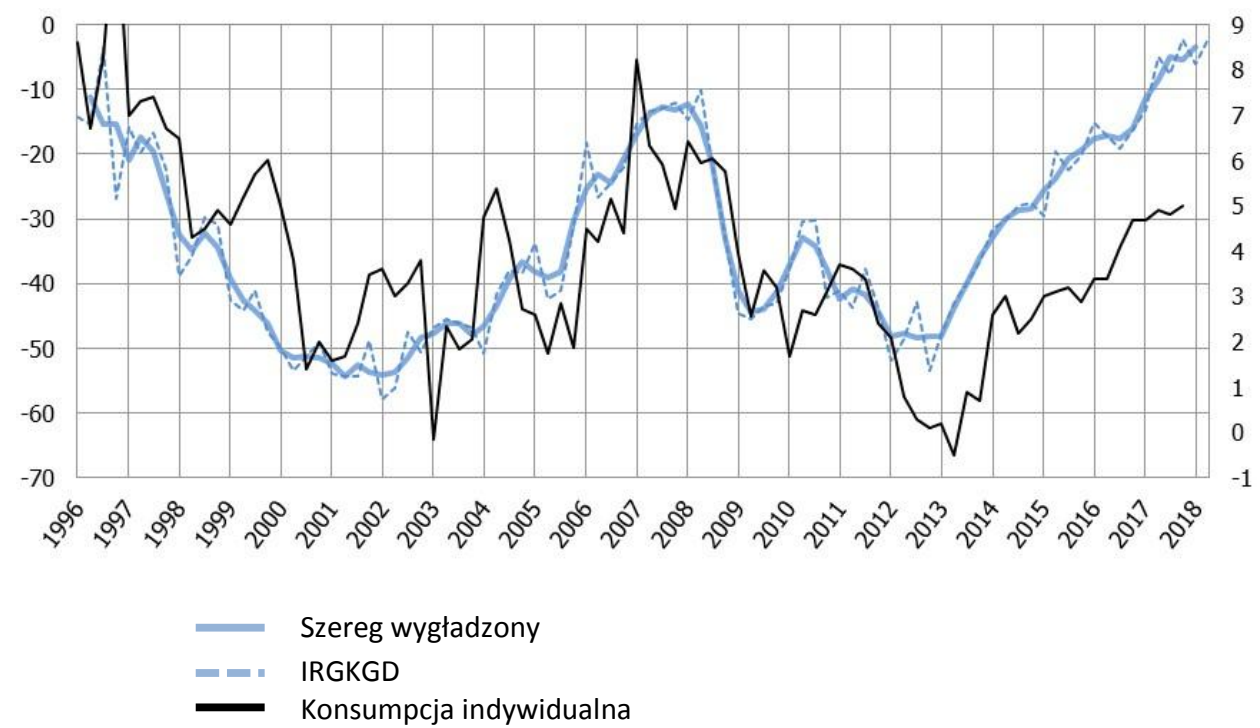

Wykres 5. Wskaźnik kondycji gospodarstw domowych

Źródło: [www2, dostęp: 8.06.2018], opracowanie: S. Dudek.

Jednym z najważniejszych, a zarazem optymistycznym wynikiem jest nieustanny wzrost osób skłonnych do oszczędzania. Jak podaje Fundacja, poziom ten wzrósł z 41\% w 2008 roku do 59\% w roku 2015. Przez te lata wzrósł także realny dochód gospodarstw domowych - zmiana o 10 punktów procentowych. Polacy niezmiennie uważają, że warto oszczędzać. W praktyce jednak okazuje się, że nasza narodowość ma z tą sferą ekonomii bardzo duże problemy. Bardzo często oszczędzają tylko przez chwilę, pod wpływem panującej mody. Bardziej dbają o przyszłość, a mniej o drobne przyjemności. Są bardzo podatni na zmiany makroekonomiczne otoczenia, w którym się znajdują. Są przy tym coraz bardziej odpowiedzialni i świadomi, gromadząc środki na skonkretyzowane cele - przyjemności, wakacje, bądź zabezpieczenie przyszłości najbliższych osób. Jednocześnie warto wspomnieć, że w ciągu 3 lat Polacy niejako przewartościowali cele swoich oszczędności, bowiem o ile w 2013 roku były to cele rekreacyjne, o tyle w roku 2015 było to zapewnienie płynności finansowej rodziny na przyszłość [Postawy Polaków wobec finansów, 2015: 4].

Polskie rodziny przede wszystkim rozmawiają. Kwestie dotyczące większych wydatków są poruszane i dyskutowane w więcej niż $60 \%$ gospodarstw domowych. Dodatkowe nadwyżki finansowe są gromadzone na rachunkach bankowych, a tym samym zmniejsza się stopień wydatków niezaplanowanych - w 2015 roku odnotowano wzrost o 6 punktów procentowych w porównaniu 
z rokiem 2013 - 15\% wówczas planowało wydatki. Średni poziom zaoszczędzonych wydatków to kwoty w przedziale 101-250 złotych [Postawy Polaków wobec finansów, 2015: 36], deklarowane przez 36\% badanych. Polacy planują krótkoterminowo. Najczęstszym okresem planowania swoich finansów jest miesiąc. Jest to spowodowane comiesięcznymi wypłatami, co pozwala zatrzymać się i pochylić nad wydatkami na najbliższy czas. Kontrolowane są zazwyczaj wszystkie wydatki, a więc nie tylko te związane z zakupem droższych urządzeń, czy opłatą czynszu, ale także te, które umożliwiają człowiekowi funkcjonowanie - żywność, komunikacja. Takowy sposób kontroli finansów deklaruje co trzeci ankietowany.

W polskich domach brakuje natomiast świadomości swojej emerytury w przyszłości. Polacy wolą o niej nie myśleć. Jedynie $21 \%$ ankietowanych zadeklarowało oszczędzanie z myślą o swojej emeryturze [Postawy Polaków wobec finansów, 2015: 33]. Połowa ankietowanych w dalszym ciągu nie jest świadoma kwoty świadczenia, należącego się im po wielu latach pracy. Pokazuje to, że niezbędną jest zmiana polskiego systemu emerytalnego, a także zapewnienie dostępu do informacji w tak ważnej sferze naszego życia.

Badania fundacji pokazują, że Polacy, choć deklarują i starają się oszczędzać i planować swoje wydatki, mają z tym problem. Perspektywy na przyszłe lata są jednak obiecujące. Zmiany systemu emerytalnego, a także zmiany makroekonomiczne naszego otoczenia w przyszłości wywołają wzrost świadomości finansowej wśród mieszkańców naszego kraju.

\section{PODSUMOWANIE}

Analizując strukturę zarządzania budżetem gospodarstw domowych warto uwzględnić także nasze gospodarstwa, które na co dzień tworzymy. Biorąc pod uwagę zmiany gospodarcze w naszym kraju do pewnego momentu jesteśmy w stanie interweniować oraz zmienić sytuację naszego gospodarstwa, co w dłuższym okresie przyczyni się do wpływów do naszego domowego budżetu oraz pozwoli na lepsze zarządzanie finansami.

Zmierzając do konkluzji, patrząc na wyniki poszczególnych kategorii i statystyk możemy wywnioskować, że istnieje potrzeba nieustannej pracy nad rozwojem technologii, demografii, dostępu do informacji oraz relacji społecznych w celu poprawy jakości życia obywateli. 


\section{BIBLIOGRAFIA}

Badanie TNS OBOP, 2006, Planowanie budżetów domowych oraz podejmowanie ważnych decyzji finansowych.

Bywalec C., 2009, Ekonomika i Finanse Gospodarstw Domowych, Wydawnictwo Naukowe PWN, Warszawa.

Dochody i warunki życia ludności Polski (raport z badania EU-SILC 2009), 2011, GUS, Warszawa.

Dryszel A., Kęciek K., Tumiłowicz B., 2012, Zarządzanie Budżetem domowym, NBP Portal, NBP, Warszawa.

Forlicz S. (red.), 2012, Gospodarstwo domowe jako przedmiot badań ekonomicznych, „Zeszyty Naukowe Wyższej Szkoły Bankowej we Wrocławiu”, nr 31/2012, Wydawnictwo Wyższej Szkoły Bankowej w Poznaniu, Poznań.

Łysoń P. (red.), 2011, Ochrona zdrowia w gospodarstwach domowych w 2010 r., GUS, Departament Badań Społecznych i Warunków Życia, Warszawa.

Łysoń P. (red.), 2015, Budżety Gospodarstw Domowych w 2014 r., GUS, Departament Badań Społecznych i Warunków Życia, Warszawa.

Łysoń P. (red.), 2016, Budżety Gospodarstw Domowych w 2015 r., GUS, Departament Badań Społecznych i Warunków Życia, Warszawa.

Łysoń P. (red.), 2017, Budżety Gospodarstw Domowych w 2016 r., GUS, Departament Badań Społecznych i Warunków Życia, Warszawa.

Kopystyńska A., 2015, Style zarzadzania domowym budżetem Polaków pozostających w statych zwiazkach, DOI: 10.15678/PJOEP.2015.08.01.

Milic-Czerniak R. (red.), 1998, Gospodarstwa Domowe w krajach Europy Środkowej, Instytut Spraw Publicznych, Warszawa.

Musiał M., 2015, Zastosowanie instrumentów zarzadzania Finansami osobistymi $w$ polskich gospodarstwach domowych, Szkoła Główna Handlowa.

Ochrona zdrowia w gospodarstwach domowych w 2010 r., 2011, GUS, Departament Badań Społecznych i Warunków Życia, Warszawa.

Postawy Polaków wobec Finansów, 2015, Badanie Fundacji Kronenberga przy Citi Handlowy, Warszawa, wrzesień.

Poświata J. (red.) 2017, Informacja o sytuacji społeczno-gospodarczej województw, GUS, Warszawa.

Siwiak K. (red.) 2014, Sytuacja gospodarstw domowych w 2013 r. w świetle wyników badania budżetów gospodarstw domowych, GUS, Warszawa.

Świetlik K., 2011, Zarządzanie budżetem przez gospodarstwa domowe, „Handel Wewnętrzny”, nr 5, IERIGŻ-PIB - Warszawa.

[www1] http://innpoland.pl/141499,technologie-w-sluzbie-oszczedzania-aplikacje-do-zarzadzaniabudzetem [dostęp 7.06.2018].

[www2] http://kolegia.sgh.waw.pl/pl/KAE/struktura/IRG/koniunktura/Strony/kondycja.aspx [dostęp 8.06.2018].

[www3] https://wpolityce.pl/spoleczenstwo/279748-niepokojace-dane-gus-na-temat-rodzinyspada-liczba-malzenstw-rodzi-sie-coraz-mniej-dzieci?strona=4 [dostęp 27.02.2018].

[www4] http://www.portalsamorzadowy.pl/polityka-i-spoleczenstwo/glowny-urzad-statystycznypoliczyl-ile-dzieci-maja-polskie-rodziny,87581.html [dostęp 27.02.2018]. 


\title{
SOCIAL, DEMOGRAPHIC, ECONOMIC AND GEOGRAPHICAL CONDITIONS FOR THE BUDGET MANAGEMENT IN POLAND
}

\begin{abstract}
The basic task of households is spending and satisfying the needs of its users. Each of us, creates households, generates income for the family budget, regardless of age, gender, personal or health situation. Over the years, the process of managing incomes and expenses has evolved. Nowadays, these changes are very important in the era of general access to information. However, are we aware of changes in the structure of household budget management and its impact on society? The following article presents the structure of changes in managing the budget of households in demographic, economic, demographic and social terms based on statistical, empirical and available scientific literature. The following article presents the structure of changes in managing the budget of households in demographic, economic, demographic and social terms based on statistical, empirical and available scientific literature. The results of the Kronenberg Foundation's research at the Citi Handlowy bank will be presented, concerning the economic situation of households and Poles' attitudes towards finances. The most favorable option of managing the household budget will be selected and guidelines will be presented aimed at popularizing and streamlining the household budget management process.
\end{abstract}

Keywords: budget, home budget, economy, management, income, expenses, demography, structure. 